\title{
TEACHING SPEAKING THROUGH AUDIO LANGUAGE LEARNING
}

\author{
By: Abd. Muin
}

\begin{abstract}
ABSTRAK: Prinsip dari Metode Audio Language adalah guru harus menjadi model bagi pelajar dalam kelas dan sipelajar sebagai peniru model. Artinya, jika ada pengucapan yang salah dalam interaksi, seorang pengajar boleh secara langsung mengoreksi. Akan tetapi, ketika sipelajar melakukan cara yang benar atau pengucapan yang tepat, guru sebaiknya memberikan penguatan atau memuji sipelajar. Perinsip lain daripada metode Audi Language adalah sipelajar harus dibiasakan untuk menggunakan bahasa sasaran dan meminimalisasi penggunaan bahasa ibu sipelajar. Metode Audio Language cocok digunakan dalam pengajaran 'speaking' untuk meningkatkan kemampuan sipelajar berbicara. Terdapat tujuh belas prinsip metode Audi Language yang harus diikuti secara bertahap bagi guru yang mau mengajar 'speaking' menggunakan metode ini.
\end{abstract}

KATA KUNCI: Education, principle, model, imitator, speaking, interaction, classroom, and management.

TO MOST people, mastering the art of speaking in the single most important aspect of learning foreign language, and success in measuring in term of the ability to carry out a conversation in the language. ${ }^{1}$

The communication between humans is an extremely complex and ever-changing phenomenon, and it is not my intention to examine all the many variables that are involved. But there are certain generalizations that we can make about the majority of communication events and these will have particular relevance for the learning and teaching foreign language. ${ }^{2}$ Furthermore, he summarizes that why do people want to communicate to others? because of the reasons are as follows:

1. They want to say something

2. They have some communicative purposes.

3. They select from their language store.

4. They want to listen to something.

5. They are interested in communicative purposes of what is being said.

6. They process a variety of language. 
Speaking in another language involves not only stripping oneself of the prospective devices as well known language makes available to us but also reverting to a much less nature level of expression that can make the adolescent and adult learners feel foolish. ${ }^{3}$

When they are engaged in communication, foreign language learners often have communicative intentions which they find difficulty in expressing, because of gaps in their linguistic repertoire. If a learner is able to anticipate such a problem, he may be able to forestall it by avoiding communication or modifying what he intends to say. If the problem arises while the learner is ready engaged in speaking, he must try to find an alternative way of getting the meaning across. In either case, his way of coping with the situation is what we call his communication strategy. ${ }^{4}$

Based on the explanation above, it seems that speaking is one aspect should be mastered by the foreign language learners. Therefore, it is needed the appropriate method in teaching it.

One of alternative solution will be offered in this paper is Audio Language Learning Method. This method is considered can show the way out to overcome the problems face by learners in learning speaking.

The starting point for all language teaching should be an understanding of how the learners learn. But it is too often the case that 'learning' factors are the last to be considered. ${ }^{5}$

As a language teacher we should make decisions all of the time. Some of our decisions are relative minor ones-should homework be assigned that particular day, for example, other decisions have more profound implications. What should be the goal of language instruction? Which language teaching method will be the more effective in reaching? What is the best means of evaluation to see if it has been reached? There is no single correct answer to question like these. Each of us should answer by ourselves. It is believed, however, that a teacher informed about some of the possibilities will make better decisions. ${ }^{6}$

The teaching of foreign language such as English is a major international enterprise. The current status of English has turned a significant percentage of the world's population into part -time users or learners of English. The widespread need of English as a second or foreign language puts a consideration pressure on the educational resources of many countries including Indonesia. Problems relating to the teaching of English as foreign language faced by the Indonesian English teachers. ${ }^{7}$

Nunan ${ }^{8}$ states that for much of its history, language teaching has been obsessed with a search for the 'right' method. It was felt that somewhere or other there was a method which would work for all learners in all contexts, 
and that once such a method has been found the language teaching problem would be solved once and for all. More recently, it has been realized that there never was and probably never will be a method for all, and the focus in recent years has been on the development of the classroom task and activities which are consonant with that we know about processes of foreign language acquisition, and which are also in keeping with dynamic of the classroom itself.

Furthermore, he explains that given this shift away from a focus on method, it might seem odd, because some teachers are aware of where they have come from as a profession. It is also interesting to note the ways in which theoretical and ideological believes about the nature of language and learning as well as the result of empirical research, have been realized at the level of pedagogical action.

\section{AUDIO-LANGUAGE METHOD}

Audio Language method had a greater impact on foreign language teaching than any other method. Unlike some of the more loosely formulated methods which grew out humanistic psychology, it consists of a highly coherent and well developed classroom pedagogy, with clear links between theory and practice. ${ }^{9}$

The Audio Language Method, like the Direct Method we have just examined, has a goal very different from that of the Grammar Translation method. The Audio-Lingual Method was developed in the United States during Word War II. At that time there was a need for people to learn foreign languages rapidly for military purposes. As we have seen, the Grammar-Translation Method did not prepare people to use the target language. While communication in the target language was the goal of the Direct Method, there were at the time exciting new ideas about language and learning emanation from the disciplines of descriptive linguistics and behavioral psychology. These ideas led to the development of the AudioLingual Method. Some of the principles are similar to those of the Direct Method, but many are different, having been based upon conceptions of language and learning from these two disciplines. ${ }^{10}$

Unlike Freemen, Lado ${ }^{11}$ states that Audio Language Method movement stands out as one of greatest efforts to improve the teaching foreign language in the United States. It was attempt to adapt the experience and success of the ASTP intensive language program to school curriculum.

Lado gives more explanation that there were inherent limitations in the adaptation of the method to the three to five periods a week, the teacher must handle the class single handedly-that is without the aid of a native speaking informant and intensive ASPT course, and finally the motivation of students to master foreign language is not always present. 
The basic principle is that Audio Language Method band of language is the central one and it can operate without assistance from eye. The second principle is a changing in performance that occurs through practice.

In order to and understanding of this method, let us now enter a classroom where the Audio-Lingual Method is being used. We will sit in on a beginning level English class in Mali. There are thirty-four students, thirteen to fifteen years of age. The class meets for one hour a day, five days a week.

\section{EXPERIENCE}

As we enter the classroom, the first thing we notice is that the students are attentively listening as the teacher is presenting a new dialog, a conversation between two people. The students know they will be expected to eventually memorize the dialog the teacher is introducing. All of the teacher's instructions are in English. Sometimes she uses actions to convey meaning, but no one word of the students' mother tongue is uttered. After she acts out the dialog, she says:

"All right, class. I am going to repeat the dialog now. Listen carefully, but no talking please".

Two people are walking along a sidewalk in town. They know each other, and as they meet, they stop to walk. One of them is named Sardy and the other one is named Mell. I will talk for Sardy and for Mell. Listen to their conversation:

$\begin{array}{lll}\text { Sardy } & : \text { Good morning Mell. } \\ \text { Mell } & : \text { Good morning Sardy } \\ \text { Sardy } & : \text { How are you? } \\ \text { Mell } & : \text { Fine, thanks, and you? } \\ \text { Sardy } & : \text { Fine, where are you going? } \\ \text { Mell } & : \text { I'm going to the campus } \\ \text { Sardy } & : \text { I am too. Shall we go together? } \\ \text { Mell } & : \text { Sure. Let's go. }\end{array}$

"Listen one more time. This time try to understanding all that I am saying."

Now she has the whole class repeat each of the lines of the dialog after her model. They repeat each line several times before moving on to the next line. When the class comes to the line, " $\mathrm{I}$ ' $\mathrm{m}$ going to the campus, "they stumble bit in their repetition. The teacher, at this point, stops the repetition and uses a backward build-up drill (expansion drill). The purpose of this drill is to break down the troublesome sentence into smaller parts. The teacher stats with the end of the sentence and has the class repeat 
just the last two words. Since they can do this, the teacher adds a few more words, and the class repeats this expanded phrase. Little by little the teacher builds up the phrases until the entire sentence is being repeated.

$\begin{array}{lll}\text { Teacher } & : \text { Repeat after me: campus } \\ \text { Class } & : \text { campus } \\ \text { Teacher } & : \text { To the campus } \\ \text { Class } & : \text { To the campus } \\ \text { Teacher } & : \text { going to the campus } \\ \text { Class } & : \text { going to the campus } \\ \text { Teacher } & : \text { I am going to the campus. } \\ \text { Class } \quad: \text { I am going to the campus.. }\end{array}$

Through this step by step procedure, the teacher is able to give the students help in producing the troublesome line. Having worked on the line in small pieces, the students are also able to take note of where each word or phrase begins and ends in the sentence.

After the students have repeated the dialogue several times, the teacher gives them change to adopt the role of Bill while she says Sally's line. Before the class actually says each line, the teacher models it. In effect, the class is experiencing a repetition drill where the task is to listen carefully and attempt to mimic the teacher's model as accurately as possible.

Next the class and the teacher switches roles in order to practice a little more, the teacher saying Bill's lines and the class saying Sally's, and so on.

To make clear how to use Audio Language Method, let's look the observations and principles in the classroom interaction is given by Freeman ${ }^{12}$ as follows:

\begin{tabular}{|c|c|}
\hline Observations & Principles \\
\hline $\begin{array}{l}\text { 1. The teacher introduce a } \\
\text { new dialog }\end{array}$ & $\begin{array}{l}\text { Language forms do not occur } \\
\text { by themselves; they occur most } \\
\text { naturally within a context. }\end{array}$ \\
\hline $\begin{array}{l}\text { 2. The language teacher uses } \\
\text { only the target language in } \\
\text { the classroom. Actions, } \\
\text { pictures, or realia are used } \\
\text { to give meaning otherwise. }\end{array}$ & $\begin{array}{l}\text { The native and the target } \\
\text { language have separate } \\
\text { linguistic systems. They should } \\
\text { be kept apart so that the } \\
\text { students' native language } \\
\text { interference as little as possible } \\
\text { with the students' attempt to } \\
\text { acquire the target language. }\end{array}$ \\
\hline
\end{tabular}




\begin{tabular}{|c|c|c|}
\hline & $\begin{array}{l}\text { The language teacher } \\
\text { introduces the dialog by } \\
\text { modeling in two times; he } \\
\text { introduces the drills by } \\
\text { modeling the correct } \\
\text { answers; at other times, he } \\
\text { corrects mispronunciation } \\
\text { by modeling the proper } \\
\text { sounds in the target } \\
\text { language. }\end{array}$ & $\begin{array}{l}\text { One of the language teacher's } \\
\text { major roles is that of a model } \\
\text { of the target language. } \\
\text { Teachers should provide the } \\
\text { students with a native speaker- } \\
\text { like model. By listening to how } \\
\text { it is supposed to sounds, } \\
\text { students should be able to } \\
\text { mimic the model. }\end{array}$ \\
\hline & $\begin{array}{l}\text { The students repeat each } \\
\text { line of the new dialog } \\
\text { several times. }\end{array}$ & $\begin{array}{l}\text { Language teaching is a process } \\
\text { of habit formation. The more } \\
\text { often something is repeated, } \\
\text { the stronger the habit and the } \\
\text { greater the learning. }\end{array}$ \\
\hline 5. & $\begin{array}{l}\text { The students stumble over } \\
\text { one of the line of dialog. } \\
\text { The teacher uses a } \\
\text { backward build-up drill } \\
\text { with this line. }\end{array}$ & $\begin{array}{l}\text { It is important to prevent } \\
\text { learners from making errors. } \\
\text { Errors lead to the formation of } \\
\text { bad habits. When the errors do } \\
\text { occur, they should be } \\
\text { immediately corrected by the } \\
\text { teacher. }\end{array}$ \\
\hline 6. & $\begin{array}{l}\text { The teacher initiates a } \\
\text { chain drill in which each } \\
\text { students greets another. }\end{array}$ & $\begin{array}{l}\text { The purpose of language } \\
\text { learning is to learn how to use } \\
\text { the language to communicate. }\end{array}$ \\
\hline 7. & $\begin{array}{l}\text { The teacher uses single-slot } \\
\text { and multiple-slot } \\
\text { substitution drill. }\end{array}$ & $\begin{array}{l}\text { The particular parts of speech } \\
\text { occupy particular "slot" in } \\
\text { sentences in order to create } \\
\text { new sentences, the students } \\
\text { must learn which part of the } \\
\text { speech occupies which slot. }\end{array}$ \\
\hline 8. & $\begin{array}{l}\text { The teacher says, "Very } \\
\text { good", when the students } \\
\text { answer correctly. }\end{array}$ & $\begin{array}{l}\text { Positive reinforcement helps } \\
\text { the students to develop correct } \\
\text { habit. }\end{array}$ \\
\hline 9. & $\begin{array}{l}\text { The teacher uses spoken } \\
\text { cues and picture cues. }\end{array}$ & $\begin{array}{l}\text { Students should learn to } \\
\text { respond to both verbal and } \\
\text { non-verbal stimuli. }\end{array}$ \\
\hline
\end{tabular}




\begin{tabular}{|c|c|}
\hline $\begin{array}{l}\text { 10. The teacher conducts } \\
\text { transformation and } \\
\text { question and answer drill. }\end{array}$ & $\begin{array}{l}\text { Each language has a finite } \\
\text { number of patterns. Pattern } \\
\text { practice helps students to form } \\
\text { habit which enable the } \\
\text { students to use the patterns. }\end{array}$ \\
\hline $\begin{array}{l}\text { 11. When the students can } \\
\text { handle it, the teacher poses } \\
\text { the question to them } \\
\text { rapidly. }\end{array}$ & $\begin{array}{l}\text { Students should "over learn" } \\
\text { i.e. learn to answer } \\
\text { automatically without } \\
\text { stopping to think. }\end{array}$ \\
\hline $\begin{array}{l}\text { 12. The teacher provides he } \\
\text { students which cues he } \\
\text { calls on individuals, he } \\
\text { smiles encouragement, he } \\
\text { holds up picture one after } \\
\text { another. }\end{array}$ & $\begin{array}{l}\text { The teacher should be like an } \\
\text { orchestra leader conducting, } \\
\text { guiding, and controlling the } \\
\text { students' behavior in the target } \\
\text { language. }\end{array}$ \\
\hline $\begin{array}{l}\text { 13. New vocabulary introduce } \\
\text { through lines of the dialog, } \\
\text { vocabulary is limited. }\end{array}$ & $\begin{array}{l}\text { The major objective of } \\
\text { language teaching should be } \\
\text { for the students to acquire the } \\
\text { structural patterns; students } \\
\text { will learn vocabulary } \\
\text { afterward. }\end{array}$ \\
\hline $\begin{array}{l}\text { 14. Students are given no } \\
\text { grammar rules, } \\
\text { grammatical points are } \\
\text { taught through examples } \\
\text { and drills. }\end{array}$ & $\begin{array}{l}\text { The learning of a foreign } \\
\text { language should be the same } \\
\text { as the acquisition of the native } \\
\text { language. We do not need to } \\
\text { memorize rules in order to use } \\
\text { our native language. The rules } \\
\text { necessary will be figured out } \\
\text { or introduce from examples. }\end{array}$ \\
\hline $\begin{array}{l}\text { 15. The teacher does a } \\
\text { contrastive analysis of the } \\
\text { target language in order to } \\
\text { locate the places where he } \\
\text { anticipates his students } \\
\text { will have trouble. }\end{array}$ & $\begin{array}{l}\text { The major challenging of } \\
\text { foreign language teaching is } \\
\text { getting the students to } \\
\text { overcome the habits of their } \\
\text { native language. A comparison } \\
\text { between the native and the } \\
\text { target language will tell the } \\
\text { teacher in what areas his } \\
\text { students will probably } \\
\text { experience difficulty. }\end{array}$ \\
\hline
\end{tabular}




\begin{tabular}{|l|l|}
\hline $\begin{array}{l}\text { 16. The teacher writes the } \\
\text { dialog on the whiteboard } \\
\text { toward the end of the } \\
\text { week. The students do } \\
\text { some limited written work } \\
\text { with the dialog. }\end{array}$ & $\begin{array}{l}\text { Speech is more basic to } \\
\text { language than the written } \\
\text { form. The natural order-the } \\
\text { older children follow when } \\
\text { learning their native language- } \\
\text { of skill acquisition is, listening, } \\
\text { speaking, reading, and writing. }\end{array}$ \\
\hline $\begin{array}{l}\text { 17. The supermarket alphabet } \\
\text { game and a discussion of } \\
\text { the Indonesian } \\
\text { supermarkets and football } \\
\text { include. }\end{array}$ & $\begin{array}{l}\text { Language cannot be separated } \\
\text { from culture. Culture is not } \\
\text { only literature and the arts, but } \\
\text { also the everyday behavior of } \\
\text { the people who use the target } \\
\text { language. One of the teacher's } \\
\text { responsibilities is to present } \\
\text { information about the culture. }\end{array}$ \\
\hline
\end{tabular}

\section{THE NATURE OF COMMUNICATION}

Communication between humans is an extremely complex and everchanging phenomenon, and it is not my intention to examine all the many variables that are involved. But there are certain generalizations that we can make about the majority of communicative evens and these will have particularly relevance for the learning and teaching foreign languages. ${ }^{13}$

Furthermore, he explains that when two are engaged I taking to each other we can be fairly sure that are doing so for good reasons. He divides six reasons that cause the people communicates one another. There are as follows:

1. They want to say something. Want is used here in a general way to suggest that speakers make definite decisions to address other people speaking may, of course, be forced upon them, but we can still say that they feel the need to speak, otherwise they would keep silent.

2. They have some communicative purposes. The speakers say thing because they want to something to happen as a result of what they say. They may want to charm their listeners; they may want to give some information or express pleasure. They may decide to be rude or to flatter, to agree or to complain. in each of these case they are interested in achieving this communication purposes-what is important is the massage they wish to convey and the effect they want to have.

3. They select from their language store. Speakers have an infinite capacity to create new sentences. In order to achieve this communication purposes they will select. The language they think is appropriate for this purposes.

4. They want to listen something. Once again 'want' is used in a general way. 
But in order for someone to understand what they are listening to (or reading) they must have desire to do so.

5. They are interested in the communicative purpose of what is being said. In general people listen to language because they want to find out what the speaker is trying to say, in other words, what ideas they are conveying, and what effect they wish the communication to have.

6. They process a variety of language. Although the listener may have a good idea of what the speaker is going to say next, in general terms, he or she has to be preferred to process a great variety of grammar and vocabulary to understand exactly what is being said.

The items above indicate that whenever communication takes place, of course, there is a speaker and a listener, and both of them perform a communication act.

\section{GROUP WORK AND CONTENT LEARNING}

Speaking activities are very often used to master content matter. Group work in most school classes is used not for the language activity it provides, but because through trying to understand texts, experiencing activities producing material, or problem-solving activities, learners master the content matter of the object they are studying.

There are three ways to help the learners in order to do speaking activities, as follows:

1. The speaking activities involve the active processing of the content. A simple version of this type of the activity may involve learners working together to answer a set of questions based on a given text or to solve a puzzle.

2. The speaking activity requires previous master of the content. Some jigsaw activities require learners to master material which they then teach to other in the group. Each learner has a different piece of material to master and then teach. All the pieces go together to make up a complete unit.

3. The speaking activity gives rise to the content which comes mainly from the learners' own experience. This particular true where speaking activities are used as a means to develop cultural awareness trough the use of role plays or personal awareness through the use of humanistic techniques.

\section{WHAT IS THE PRINCIPLE OF GROUP WORK?}

There are several factors cause work group. To result in group work

where everyone involved is interested, active and thoughtful. If these three 
factors agree with each other, then the group work is likely to be successful. In they are not in agreement, group work is likely to be unsuccessful .the five factors are:

1. The learning goals of group work

2. The task

3. The way information is distributed

4. The seating agreement of the member of the group, and

5. The social relation between the members of the group.

\section{WHAT IS THE GOAL OF GROUP WORK?}

The following description of the goals of group work focuses on the spoken use of language. There are several reasons for this focus. Firstly, group work is most commonly used to get learners interesting orally. Secondly, research in the group work in language learning has studied spoken activity partly because this is the most easily observed and recorded. Thirdly, most of the teachers use speaking activities in unprincipled ways. One of the aims of this discussion is to suggest how such activities can be used and adapted to achieve language learning goals. ${ }^{14}$

\section{GENERAL PRINCIPLES OF TEACHING}

1. Listening and speaking come before reading and writing. the students should be given plenty of opportunities to listen to correct English before being asked to speak.

2. Lessons should be enjoyable and stimulating, so that students want to take part.

3. Students must be given every opportunity to use language for a real purpose, so that the language is meaningful. In this way real communication takes place. This is the aim of the activities.

4. The teacher should not progress too fast. Go at the pace the students can manage, and give additional practice where necessary.

5. Do not present too many language items at once: one new pattern of about four or five words is enough for one lesson. Students should need to use the pattern or word for a real purpose.

6. Constant revision is essential. Revision has been built into this course but the teacher should provide additional revision of anything known to give difficulty. A few minutes revision at the beginning of each lesson is often very valuable. 
7. Grammar should not be explained. The aim is to teach students to use language, not to learn about it.

8. Do not translate words or explain them unless it is unavoidable. Show students the meanings of words.

9. Be encouraging. Do not discourage or scold. Smile and give praise for trying. Learning a new language can be stressful.

10. Speak clearly but naturally, and at a normal speech. Do not pause between words unnecessary.

11. Make sure that all students are taking part.

12. Do not talk too much. The more English used by the students, the more successful the lesson.

13. Do not continue an activity too long. Young students can quickly lose interest.

14. Prepare your lesson. This will only take a few minutes using the brief teaching notes. An unprepared lesson is seldom successful.

15. Give pronunciation guidance when it is needed and it usually is.

16. Do not ask the students to spell out words. They learn words by using them orally, and then reading and writing them.

17. Remember that teaching and testing are two different things.

18. Vary activities to avoid boredom.

19. Try to include some physical movement, e.g. students coming to the front, following instructions and pointing. Young students especially do not like to sit still.

20. Try to make your lessons interesting and enjoyable; the students will learn more in a shorter time. ${ }^{15}$

\section{THE ROLE OF THE TEACHERS IN THE CLASSROOM INTERACTION}

In this part, the writer is going to present briefly the role of the teacher in the classroom. According to Harmer, there are eight roles of the teachers, as follows: as controller, assessor, organizer, prompter, participant, a resource, tutor, and investigator.

\section{Teacher as Controller}

The teachers as a controllers means that they control not only what the students do but also when they speak and what language they use in the classroom.

The teachers as controller is closely allied to the image that teacher project of themselves. Some appear to be neutral leaders and performers, while some are quieter and feel happier when the students are interacting amongst themselves. Where then teachers are addicted to being center of 
attention they tend to find it difficult not to perform the controlling role and this has both.

\section{Teacher as Assessor}

Clearly a major part of the teacher's job is to assess the students' work, to see how well they performing or how well they performed. Not only is this important pedagogically, but the students quite naturally expect it, even after communicative activities. ${ }^{16}$

\section{The Teacher as Organizer}

Perhaps the most important and difficult role of the teacher has to play is that of organizer. The success of many activities depends on good organization and on the students knowing exactly what they are to do. A lot of time can be wasted if the teacher omits to give the students vital information or issues conflicting and confusing instruction.

The main aim of the teacher when organizing an activity is to tell the students what they are going to talk about (or write or read about), give clear instruction about what exactly their task is, get the activity going, and then organize feedback when it is over. ${ }^{17}$

\section{The Teacher as Prompter}

Often the teacher needs to encourage students to participate or needs to make suggestion about how students may proceed about an activity when there is a silence or when they are confused about what to do next. This is one of the teacher's important roles, the role of prompter.

The role of prompter has to be performed with discretion for if teachers are too aggressive they start to take over from the students, whereas the idea is that they should be helping them only when it is necessary. 18

\section{The Teacher as Participant}

There is no reason why the teacher should not participate as an equal in an activity especially where activities like simulations are taking place. Clearly a lot of occasions it will be difficult for us to do so as equals (since we often know all the material and all detail, etc. ${ }^{19}$

\section{The Teacher as a Source}

We have stressed the importance of teacher non-intervention where a genuinely communicative activity is taking place in the classroom and this means that the teacher is left, to some extent, with nothing to do. In other words, the teacher should always be ready to offer help if it is needed.20 


\section{The Teacher as Tutor}

We can talk about the teacher as a tutor in the sense of someone who acts as a coach and as a resource where students are involved in their own work, and call upon the teacher mainly for advice and guidance. This is the role the teacher adopts where students are involved in self-study or where they are doing project work of their own choosing. The teacher will be able to help them by clarify ideas and limit the task, for example; the teacher can help them by pointing out errors in rough drafts; the teacher cab also offer the students advice about how to get the most out of their learning and what to do if they want to study more. ${ }^{21}$

\section{The Teacher as Investigator}

The teachers are not only teaching in the classroom, but also they should investigate what is going on, on the other hand, they should observe what works well in classroom, and what does not, trying out new techniques and activities and evaluating their approperiacy.

The teachers do not investigate the efficiency of new methods and who do not actively seek their own personal and professional development may find the job of teaching becoming increasingly monotonous. Teachers who constantly seek to enrich their understanding of what learning is all

about and what works well, on the other hand, will find the teaching of English constantly rewarding. 22

\section{THE MANAGEMENT OF INTERACTION IN THE CLASSROOM}

In the special sense interaction is a sort of co-production and it is worth spending some time on the completions this idea involves. The main problem is that successful interaction in the classroom, or anywhere, involves everybody managing at least five different things, at the same time. These five factors are listed below as questions, along with the labels they are usually given in the classroom research literature:

1. Who gets to speak? (participants' turn distribution)

2. What do they talk about? (topic)

3. What does each participant do with the various opportunities to speak? (task)

4. What sort of atmosphere is created? (tone)

5. What accent, dialect, or, language is used? (code)

Furthermore he explains that what makes it even more complicated is the fact that these five aspects of interaction are means as well as ends. This suggests that if teachers of say, English as a foreign language want a 
particular learner to say a something, they have a variety of possibilities open to them. They can do the direct thing, and simply ask the learner to answer a question. ${ }^{23}$

\section{CONCLUSION}

After reading the content of this paper, it can be concluded that Audio Language Method is suitable to be used in teaching speaking in the classroom, because it trains the students to use target language under guided by their teacher.

Through this method, the students are provided to be good model of imitation. It means the students are imitators and the teachers as model. Whenever the students make errors sounds or pronunciation the teacher should correct directly.

New vocabulary and structure are presented through the dialogs and the dialogs are learned through imitation and repetition.

The basic principle of Audio Language Method is to make the students' habit with the target language learning and overcoming the old habits of their native language. There are seventeen principles of Audio Language Method should be followed step by step by the teacher.

\section{END NOTE:}

1. David Nunan, Language Teaching Methodology, Great Britain: Prentice Hall International (UK) Ltd, 1991, p. 39.

2. Harmer Jeremy, The Practice of English Language Teaching, Great Britain: Longman Group UK Ltd., 1991, p. 46.

3. Wilga M. Rivers, Communicating Naturally in a Second Learning (Theory and Practice Language Teaching), Cambridge: Cambridge University Press, 1983, p. 22.

4. William T. Littlewood, Foreign and Second Language Learning (Language Acquisition Research and its Implications for the Classroom), Great Britain: Cambridge University Press, 1984, p. 83.

5. Tom Hutchinson \& Waters Alan, English Specific Purposes, Great Britain: Cambridge University Press, 1986, p. 19.

6. Diane Larsen Freeman, Techniques and Principles in Language Teaching, Hong Kong: Oxford University Press, Inc., 1986, p. 1.

7. Jack Richards, The Context of Language Teaching, USA: Cambridge University Press, 1985, p. 1.

8. David Nunan, Language Teaching Methodology, p. 228.

9. David Nunan, Language Teaching Methodology, p. 229.

10. Diane Larsen Freeman, Techniques and Principles in Language Teaching, p. 31.

11. Roberto Lado, Teaching English Across Culture, Singapore: Kim, Hun Lee Printing Pte Ltd., 1988, pp. 21-22. 
12. Diane Larsen Freeman, Techniques and Principles in Language Teaching, pp. 39-42.

13. Jeremy Harmer, The Practice of English Language Teaching, Great Britain: Longman Group Limited, 1991, p. 46.

14. ISP Nation, Language Teaching Technique, New Zealand: Victoria University of Wellington, 1990, p. 30.

15. Howe DH \& M. William, English Today (Teacher's Book). England: Oxford University Press, 1985, pp. 4-5.

16. Jeremy Harmer, The Practice of English Language Teaching, p. 237.

17. Jeremy Harmer, The Practice of English Language Teaching, p. 239.

18. Jeremy Harmer, The Practice of English Language Teaching, p. 241.

19. Jeremy Harmer, The Practice of English Language Teaching, p. 241.

20. Jeremy Harmer, The Practice of English Language Teaching, p. 242.

21. Jeremy Harmer, The Practice of English Language Teaching, p. 242.

22. Jeremy Harmer, The Practice of English Language Teaching, p. 243.

23. Dick Allwright \& Kathleen Baley, Focus on the Language Classroom (An Introduction to Classroom Research for Language Teachers), Cambridge: Cambridge University Press, 1991, pp. 19-20.

\section{REFERENCES}

Allwright, Dick \& Kathleen Baley, Focus on the Language Classroom (An Introduction to Classroom Research for Language Teachers. Cambridge: Cambridge University Press., 1991.

Freeman, Diane Larsen, Techniques and Principles in Language Teaching, Hong Kong: Oxford University Press Inc., 1986.

Howe DH \& M. William, English Today (Teacher's Book). England: Oxford University Press, 1985.

Hutchinson, Tom \& Waters Alan, English Specific Purposes, Great Britain: Cambridge University Press, 1986.

Jeremy, Harmer, The Practice of English Language Teaching, Great Britain: Longman Group UK Ltd., 1991.

Lado, Roberto, Teaching English Across Culture, Singapore: Kim, Hun Lee Printing Pte Ltd., 1988.

Littlewood, William T., Foreign and Second Language Learning (Language acquisition research and its implications for the classroom), Great Britain: Cambridge University Press, 1984.

Nation, ISP, Language Teaching Technique. New Zealand: Victoria University of Wellington, 1991.

Nunan, David, Language Teaching Methodology, Great Britain: Prentice Hall International (UK) Ltd., 1991.

Richard, Jack, The Context of Language Teaching, USA: Cambridge University Press, 1987.

Rivers, Wilga M., Communicating Naturally in a Second Learning (Theory and Practice Language Teaching, Cambridge: Cambridge University Press, 1983. 